\title{
Innovative regions and industrial clusters in hydrogen and fuel cell technology
}

\author{
Madsen, Anne Nygaard; Andersen, Per Dannemand
}

Published in:

Energy Policy

Link to article, DOI:

10.1016/j.enpol.2009.03.040

Publication date:

2010

Document Version

Peer reviewed version

Link back to DTU Orbit

Citation (APA):

Madsen, A. N., \& Andersen, P. D. (2010). Innovative regions and industrial clusters in hydrogen and fuel cell technology. Energy Policy, 38(10), 5372-5381. https://doi.org/10.1016/j.enpol.2009.03.040

\section{General rights}

Copyright and moral rights for the publications made accessible in the public portal are retained by the authors and/or other copyright owners and it is a condition of accessing publications that users recognise and abide by the legal requirements associated with these rights.

- Users may download and print one copy of any publication from the public portal for the purpose of private study or research.

- You may not further distribute the material or use it for any profit-making activity or commercial gain

- You may freely distribute the URL identifying the publication in the public portal

If you believe that this document breaches copyright please contact us providing details, and we will remove access to the work immediately and investigate your claim 


\title{
Innovative regions and industrial clusters in hydrogen and fuel cell technology
}

Anne Nygaard Madsen*, Per Dannemand Andersen

Department of Management Engineering, Technical University of Denmark, Produktionstorvet, Building 426, DK-2800 Kgs. Lyngby, Denmark

*) Corresponding author:

E-mail: anny@man.dtu.dk

Phone: +4545254540

Fax: +45 45933435

\begin{abstract}
Regional governments in Europe seem to be playing an increasing role in hydrogen and fuel cell (H2FC) development. A number of regions are supporting demonstration projects and building networks among regional stakeholders to strengthen their engagement in H2FC technology. In this article we will analyse regions that are highly engaged in H2FC activity, based on three indicators: existing hydrogen infrastructure and production sites, general innovativeness, and the presence of industrial clusters with relevance for H2FC. Our finding is that regions with high activity in H2FC development are also innovative regions in general. Moreover, the article highlights some industrial clusters that create favourable conditions for regions to take part in H2FC development. Existing hydrogen infrastructure, however, seems to play only a minor role in a region's engagement. The article concludes that, while further research is needed before qualified policy implications can be drawn, an overall wellfunctioning regional innovation system is important in the formative phase of an H2FC innovation system.
\end{abstract}


Keywords: Clusters, Regions, Hydrogen,

\section{Introduction}

Innovation in energy technology is high on the political agenda in Europe, not only for reasons of energy and climate policy, but also to help increase the EU's overall competitiveness (the "Lisbon Agenda”) through initiatives such as the Competitiveness and Innovation Framework Programme (CIP). In this connection, competitiveness refers not only to minimising firms' expenditures on energy, but also (and perhaps in particular) to industry’s ability to innovate and remain competitive in the new and sustainable energy technologies.

The regional level seems to have an increasing importance in providing good political and socio-economic conditions for innovation. Asheim and Gertler (2005) have emphasised that a regional level in the governance of economic processes - between the national level and the level of clusters and firms - is important in supporting the institutional settings that can promote innovation. In a study of the impact of the global economy on innovation policy Lundvall and Borrás (1999) found that "The region is increasingly the level at which innovation is produced through regional networks of innovators, local clusters and the crossfertilising effects of research institutions". This trend seems to be confirmed by studies and actions in the H2FC area in Europe, where the regional level has been recognised as a significant driver on the pathway to a hydrogen economy. An example of this is the work done in recent years to get the local and regional authorities represented in the Fuel Cell and Hydrogen Joint Technology Initiative and the Hydrogen and Fuel Cell Platform, which has culminated in the creation of the Regions and Municipalities Partnership on Hydrogen and Fuel Cells (HyRaMP) in April 2008.

The Internet provides numerous examples of regions (remote islands, cities, local authorities, federal states, etc.) that have declared themselves hydrogen communities. In many cases, 
regional authorities have developed fully fledged strategy plans and allocated significant public financing to the achievement of the goals of such strategies. Two examples, representing small and large communities respectively, are:

o The Western Isles Hydrogen Community Plans: Creating a Pathway to the Hydrogen Economy (in the Outer Hebrides, a part of the UK)

o Fuel Cell and Hydrogen Network in North Rhine-Westphalia (a federal state in Germany)

The European project Roads2Hycom analysed 96 potential hydrogen communities, based on a call for Registration of Interest (Shaw and Mazzucchelli 2007). Their analysis shows that government or regional/local authorities are involved in nearly $80 \%$ of the registered projects. This makes regional authorities the most important actor in the field, ahead of SMEs and large corporations. The engagement of regional authorities is typically guided by energy and environmental policy concerns, but also by industrial or politico-economic policy concerns - especially in stimulating new industrial clusters based on this new technology. Since regional authorities are actively involved in stimulating H2FC technology and related industrial clusters, a range of questions arise, which form the basis of the research for this article:

o Do geographical and cluster aspects matter in the establishment of a European hydrogen energy technology innovation system?

o Are there any geographical relationships between regions with a high level of H2FC activities and:

- Existing hydrogen infrastructure and hydrogen production sites?

- Generally innovative regions in Europe?

- Existing industrial clusters in Europe?

In the next section, we introduce a general discussion on innovation systems and clusters, and how these concepts relate to the promotion of H2FC technology. Section 3 discusses 
problems of data availability. Section 4 looks at the regions in Europe that are highly engaged in H2FC development, and in sections 5, 6, and 7 we analyse whether or not there is a correlation between H2FC infrastructure, innovativeness and industrial clusters at a regional level. Section 8 discusses the results of our analysis and the implications for energy and regional policy.

\section{Innovation systems and industrial clusters}

The process of innovation is often complex and uncertain, and technological innovation is not solely a matter of technology, manufacturers and markets. Policy makers, analysts and innovators also have to address the wider framework or environment in which companies operate and from which new innovations and technologies emerge. This may be particularly true for the innovation system of H2FC technology. The successful development of a hydrogen-based energy system requires strong engagement from the public sector to help provide and resolve infrastructure issues to support its deployment.

The concept of innovation systems takes this broad view of the process of innovation. An innovation system can be defined as the "elements and relationships which interact in the production, diffusion and use of new and economically useful knowledge" (Lundvall, 1992). These elements are the various actors that constitute the system: manufacturers, suppliers, consultancy companies, public authorities, policy makers, universities, research institutions, trade associations, consumers, etc. Relationships take shape as informal or formal networks, such as project activities or buyer-supplier relationships. These relationships link the actors in interactive learning processes. For instance, the relationship between actors involved in a demonstration project is built on the exchange of knowledge and know-how. The interaction is influenced by the institutional set-up in which it takes place. This institutional set-up is comprised of laws and rules, shaped by policies that regulate the interaction between the actors. It also includes norms and codes of practice, which typically are affected by cultural differences. 
When analysing regional policy measures for promoting hydrogen communities, two theoretical branches of innovation system studies are available. Firstly, the analytical focus can be placed on the technology or the emerging industrial sector, and innovation theorists then talk about technology-specific innovation systems - TIS (Jacobsson \& Bergek 2004, Hekkert et.al. 2006, Carlson \& Stankiewicz 1991) or sectoral innovation systems - SIS (Breschi \& Malerba 1997, Malerba 2002). Secondly, the analytical focus can be placed on the geographical entity of the community, and innovation theorists then talk about regional innovation systems - RIS (Cooke, 2001; Asheim \& Gertler, 2004; Asheim \& Gertler, 2005). These two theoretical approaches are parallel to two distinct, but often related policy fields: Research and Development policy and Regional Development policy, respectively. The technology specific approach is more concerned with directing R\&D initiatives on an overall level. Its focus is on analysing barriers to and opportunities for technological development.

The regional innovation system approach is, to a greater extent, interested in directing regional innovation policy. This approach takes a more holistic view of a region's production structure. In the regional approach the administrative borders of a region define what to include in the analysis, depending on what industries are located in the region. The focus is partly on strengthening the regional innovation system's ability to innovate, and partly on improving its ability to benefit from external links. The two approaches, TIS and RIS, can therefore be seen as relevant to two different policy levels; the national (or supra-national) level and the regional level, respectively.

\subsection{Regional innovation systems and clusters}

Focus in analyses of regional innovation systems (RIS) is on the "institutional infrastructure supporting innovation within the production structure of a region" (Asheim \& Gertler, 2005). RIS emphasises the importance of a regional level of governance of economic processes, between the national level and the level of clusters and firms. 
The RIS approach focuses particularly on localised learning and intra- and interregional knowledge flows. As in the other branches of innovation system studies, learning is viewed as a socially interactive process, built on trust (Lundvall 1992, Cooke 2002). But, in the RIS, geographical proximity is often seen as a vital facilitator of innovation processes because of the tacit character of knowledge. In RIS studies, geographical proximity is thought of as one of several factors positively influencing innovation processes. Other factors are 1) specialised suppliers with a specific technology or knowledge-base, 2) regional culture such as norms, values, routines and expectations (Asheim and Gertler 2005), and 3) a certain degree of social cohesion to avoid polarisation in a region (Lundvall and Borrás 1999).

The approach of RIS is tightly connected with the concept of industrial clusters, but the two concepts should not be conflated. Clusters should be seen as more sector-specific than RIS (Asheim and Coenen 2004). The latter can in principle stretch across several sectors, because it includes the entire production structure within a region. In consequence, regional innovation systems may consist of several clusters with relevance for H2FC development.

Porter (2000) defines a cluster as a "Geographic concentration of interconnected companies, specialized suppliers, service providers, firms in related industries, and associated institutions (for example universities, standard agencies, and trade associations) in particular fields that compete but also co-operate”.

Two matters are important to notice in Porter's definition of a cluster. The first is the notion of geographical concentration. Physical proximity is seen as extremely important for the innovation process because it eases the sharing of tacit knowledge. Another important matter in the definition of a cluster is how companies are interconnected. In a cluster, companies, suppliers and service providers compete and cooperate both horizontally and vertically in the value chain. In fact, interaction between companies and their physical proximity are two sides of the same coin. They are mutually related, and that is what creates spillover in the 
form of a specialised workforce, specialised regional suppliers, information, and training facilities, which are considered to increase the productivity with which companies can compete, both nationally and globally.

Nevertheless, some studies have found that, for some high-tech sectors, physical proximity is of less importance (Mans et al. 2008). In some high-tech sectors, external relationships with companies located worldwide can be of just as great importance - or even greater - than relationships with companies located in their own region. In the case of H2FC technology, this factor should not be neglected. On the contrary, when regions formulate their policy strategies, they should probably pay special attention to how these ties can be strengthened.

From a regional policy perspective, the most commonly used policy instrument in promoting clusters has been to support network activities (Sölvell et al.2003). In the area of H2FC this has often been in the form of Public Private Partnerships (PPPs). Other policy objectives have been to promote innovation through research, development and demonstration (RD\&D) funding, creating a special brand for the region, attracting new firms and talent to the region, providing assistance to businesses, diffusing technology in the cluster, studying and analysing the cluster and its needs, etc.

H2FC industrial clusters, in Porter's version, do not yet exist, and it seems uncertain whether it is an appropriate strategy to start creating H2FC clusters from scratch. Instead, the most reasonable way for regions to promote the creation of $\mathrm{H} 2 \mathrm{FC}$ clusters seems to be to support other relevant and existing clusters in the direction of a stronger uptake of H2FC technology. In this way a region will be able to build their H2FC engagement upon competences and strengths already present in the region.

However, to create the right conditions to fulfil the vision of a hydrogen economy, the cluster approach seems to be too partial to stand alone. Its focus on segregated single clusters 
seems to be inadequate to address the system character of a future hydrogen-based energy system. Furthermore, policy directed towards a single cluster is at risk of favouring certain technology options (“picking the winner”). So regional innovation policy needs to create framework conditions for H2FC innovation that are broader based than the single cluster focus. For this purpose, a broader analytical perspective, such as the regional innovation system approach, might be more appropriate. The RIS approach provides greater insight into strengths and competences at the regional level. As an analytical tool, it can reveal the functions of the system that need support to improve the overall innovation environment in the region.

\section{Data for innovation studies}

Following the interest in innovation studies and policy analyses in recent decades, solid statistical data has been accumulated by various authorities. However, for this study one analytical challenge has been that it deals with both geographical units and distinct technologies. H2FC is a new area of industrial technology, and the data available describing and analysing its characteristics is rather limited; neither comprehensive time series have been established nor does the technology data necessarily match with regional data.

\subsection{Geographical units}

The main analytical focus in this study is on the geographical distribution of H2FC activities in EU-27, Iceland, Norway, Liechtenstein and Switzerland. Data has been mapped at NUTS level 2 by means of a geographical information system tool (GIS).

NUTS (Nomenclature d'Unités Territoriales Statistiques) was created by Eurostat as a hierarchical classification of geographical units for use in statistical production across the European Union. NUTS level 1 corresponds to a territory with a population of 3-7 million inhabitants. NUTS level 1 thus often reflects fairly high administrative levels such as the German 
Länder. The analyses made in this study are carried out at NUTS level 2 (NUTS II), defined by Eurostat as ‘basic regions’ and comprised of 268 regions in Europe. Basic regions are used by Member States for the application of their regional policies. Although this was the intention with the subdivision of NUTS II, some countries are too small in terms of population to comply with Eurostat's definition of regional geographical entities; for instance both Denmark and Luxembourg are characterised as NUTS II regions, even though they represent nations with national policy authorities. The more detailed level of NUTS III is comprised of 1213 administrative regions in Europe.

\subsection{Sources of data}

Regional innovation system and industrial cluster analyses usually draw on the vast amount of geographically oriented statistical material provided by national statistical offices and Eurostat. In Europe, comprehensive statistical data is typically available as two entries: geographical entries at the NUTS levels, and industry-level entries based on the NACE (Nomenclature statistique des Activités économiques dans la Communauté Européenne) codes. NACE is a European industry standard classification system, consisting of a 6-digit code, and data is provided by national statistical offices, based on questionnaires filled in by individual firms (for example NACE code DJ.28.22 is "Manufacture of central heating radiators and boilers”). The challenge is that codes are available for neither hydrogen nor fuel cells, and the dispersed field of energy technology is spread over many different NACE codes. A recent analysis of self-declared hydrogen clusters in the Netherlands (Mans et al. 2008) is based on a database on 166 hydrogen-related projects carried out in the Netherlands between 2000 and 2005 involving 250 Dutch actors. The database contains geographical information on each of the actors, allowing analysis of the geographical concentration of actors at the level of the so-called COROP areas. The Netherlands is divided into 40 COROP areas which correspond to Eurostat's NUTS III level. Such detailed databases are not yet available for a Europe-wide study like the present one. 
Technology specific innovation system analysis usually draws on slightly different types of statistical data from geographically oriented analysis. Bergek, Hekkert and Jacobsson (2007) have proposed a number of indicators and types of data to map the functions of technological innovation systems (TIS). Examples of indicators of the development and diffusion of knowledge are patents, bibliometrics (publications, citations), and governmental expenditures on R\&D. Examples of indicators of market formation are the size of the market (e.g. for fuel cells) and support schemes (e.g. public investment subsidies). In the context of the European Environmental Technologies Action Plan (EU ETAP), a variety of investigations have been carried out on the concept of "eco-innovation" and its indicators (Andersen, 2006). Much of such statistical information is available for energy technologies such as H2FCs. Consultancies, such as Fuel Cell Today (www.fuelcelltoday.com), provide marketbased intelligence on the fuel cell industry. Fuel Cell Quarterly, published by FuelCell.org provides similar market surveys on both fuel cells and hydrogen technology. Patent statistics can be obtained using databases like Derwent, and bibliometrics (publications and citations) can be obtained from Web of Science - familiar to most scholars. The International Energy Agency (IEA) provides statistics on governmental expenditure on energy-related R\&D; but it has only included statistics on hydrogen and fuel cells since 2004, and data is still lacking from a number of countries. Seymour, Borges \& Fernandes (2007) discussed and applied indicators such as patents, publications and citations in an analysis of European countries' public research in H2FC technology. Similarly, Lee, Mogi and Kim (2008) used the same kind of indicators to analyse scenarios for Korea's industrial potential based on this technology.

For our purposes, the problem is that this statistical data is only available at national, and not at regional levels. We are, therefore, left with having to make analyses based on what is available, and in the following sections we will analyse data available from the Roads2Hycom project (see the description and use of data below). In addition to this data, we have included data from two major studies of the spatial economy of Europe -the Re- 
gional Innovation Scoreboard and the European Cluster Observatory (www.clusterobservatory.eu).

\section{$4 \quad$ Hydrogen and fuel cells activity in Europe}

H2FC technology is an emerging technology field, and the markets for this technology are still in their formative phase; so it is not yet possible to analyse existing industrial clusters based on this technology. However, certain tendencies can be observed from analysis of the information that is available at present. Various parts of the Roads2Hycom project have provided the following data at NUTS II level:

- H2FC demonstration projects

- Hydrogen fuelling stations

- Registration of Interest (RoI) for communities undertaking large-scale H2FC projects and innovative applications

Comparison of this data indicates which European regions (at NUTS II level) are involved in H2FC activity. Although the data may not give a complete picture of all H2FC activity in Europe, it seems to be the best available at present and can provide us with a broad idea of where hydrogen activity is located.

We classified the data (for each indicator) into four intervals based on natural breaks in the data, i.e. the biggest gaps in the dataset were used to classify the data into groups (Nelson, R. 1999). We used this classification method to ensure that similar observations were grouped together in the same interval. So that we could sum the three indicators into one total score for $\mathrm{H} 2 \mathrm{FC}$ activities, we then ranked the intervals with a score from 1-4. For example, for the dataset on demonstration sites, we first classified the data into five groups: $0,1,2-3,4-5$ and $5<$. Next, we ranked the intervals with the values from 0 to 4 . The total score for each region was calculated by summarising the score for the three indicators: demonstration sites, fuelling stations, and registration of interests. All NUTS II regions with a total score higher than 
three (15 regions) have been included in the further studies. Moreover, we included one NUTS I region (Wales, NUTS-code: UKL) because the data on the Regional Innovation Scoreboard (that we use to compare the regions with later) only exists for UK regions at this level. An adding up of activities from NUTS II to NUTS level I for the UK regions ranked Wales among the most active regions in H2FC.

\subsection{Hydrogen and fuel cell demonstration projects}

Based on existing and regularly maintained databases, the European project Roads2Hycom has identified and analysed over 130 hydrogen demonstration projects in the European Union and the associated countries, Norway and Iceland (Steinberger-Wilckens and Trümper, 2007a). The demonstration projects were mostly related to transport, stationary usage, and combinations hereof. The study included and distinguished between four types of demonstration projects: in planning, in operation, completed and interrupted. Only two of the projects comprised portable use of H2FC technology.

The NUTS II regions were ranked in accordance with data for demonstration projects using the following score: 0: no demonstration projects, 1: one demonstration project, 2: two or three demonstration projects, 3: four or five demonstration projects, 4: more than five demonstration projects.

There were demonstration projects in fifteen countries. Most were located in Germany (24\%), but France, Denmark and Italy each hosted more than ten percent of the total. Steinberger-Wilckens and Trümper (2007) concluded that an early clustering of demonstration projects seems to be appearing in the German Rhein-Ruhr/Rhein-Main area and in the crossborder region of Denmark and southern Sweden. 


\subsection{Hydrogen fuelling stations}

Hydrogen fuelling stations are a prerequisite for developing the use of hydrogen in the transport sector. Based on a study by German consulting firm Ludwig-BölkowSystemtechnik, the Roads2Hycom project has analysed both existing and planned hydrogen fuelling stations for vehicles (cars and buses) in Europe. The analysis included stations in operation, stations no longer in use, and planned stations (Perrin, Steinberger-Wilckens, Trümper, 2007).

At the time of the study (late 2007), there were 35 hydrogen fuelling stations in operation in Europe. Most of these were located in Germany. Furthermore, a large number of fuelling stations were planned, especially in Scandinavia. In total, seventy-two operational or planned hydrogen fuelling stations were analysed with geographical data at NUTS III level. Data for the analysis of this study was aggregated at NUTS II level and ranked by following the natural breaks (see above) of the data set: 0: no $\mathrm{H} 2$ fuelling stations, 1: one $\mathrm{H} 2$ fuelling station, 2: two or three $\mathrm{H} 2$ fuelling stations, 3: four or five fuelling stations, 4: more than five H2 fuelling stations.

We did not distinguish between planned and operational hydrogen fuelling stations in our mapping exercise in this study. We believe that an aggregated count of fuelling stations 'in planning' and 'in operation' is adequate to indicate the level of activity. Although there is a risk that the planned fuelling stations will never be realised, at the present stage they indicate a region's intentions and can, therefore, very well illustrate the activity level.

\subsection{Registration of Interest (RoI) for communities undertaking hydrogen and fuel cell pro- jects}

In 2006, the European project Road2Hycom launched a call for "Registration of Interest” for potential hydrogen communities in Europe (in this case: EU27, EEA and acceding and candidate countries). In an overall database, 96 potential hydrogen communities were listed. Not 
surprisingly, the largest numbers of potential hydrogen communities were registered in Germany, with almost a quarter of the total. Also Italy and the UK each had more than $10 \%$ of the total number of communities. Collectively, the five Scandinavian countries accounted for 17\% of all projects (Shaw and Mazzucchelli, 2007a). From the overall database, a sample of 36 projects is included in this analysis. They are the communities which have responded to the Call for RoI for potential hydrogen communities. The call was launched in May 2006 and is regularly updated as new information becomes available.

Due to the low number of registrations, the highest count in any region is three. The ranking of the regions is therefore as follows (with a maximum score of three): 0: no RoI, 1: one RoI, 2: two RoI and 3: three RoI.

\subsection{European regions with a high level of hydrogen and fuel cell activities}

Figure 1 shows the total H2FC score of the NUTS II regions in Europe. Furthermore, the detailed results for the 16 NUTS II regions with the highest H2FC score are shown in Table 1.

INSERT FIGURE 1 ABOUT HERE

\section{INSERT TABLE 1 ABOUT HERE}

In many cases, the clustering of activities in neighbouring regions matches the location of partnerships or co-operative H2FC initiatives. The high score in the Scandinavian regions matches the location of the 'Scandinavian Hydrogen Highway Partnership' (SHHP), which focuses its collaboration on south/south-eastern Norway, the Swedish west coast and Denmark (www.scandinavianhydrogen.org). SHHP is a collaboration between three national bodies: HyNor (Norway), Hydrogen Link (Denmark) and Hydrogen Sweden. 
The score in the regions of the federal state of North-Rhine-Westphalia in Western Germany reflects the many activities carried out by the 'Fuel Cell and Hydrogen Network NRW'. One should note that the NUTS II level is well below the political entity of North-RhineWestphalia: looking at NRW requires an adding up of these activities.

In northeast Spain, there is the Aragon hydrogen initiative, started by the Spanish Ministry of Industry in 2002. The high score in Northern Italy reflects the many and varied Italian projects that have been carried out during the last decade. For example, in Lombardy: the Zero Regio project in Mantova, the Bicocca Project in Milan, and the Arese project in Arese. In Tuscany: the HBUS project in Florence and the Arezzo project. And in Piedmont: the Hydrogen system laboratory in Turin.

The German cities of Hamburg and Berlin also score among the highest ranked regions along with northeastern England, Iceland, and Nord-Pas-de-Calais in France.

\section{High-level H2FC regions and existing infrastructure and production capacities}

In this section, we will examine whether the 16 high activity H2FC regions are located in regions with existing infrastructure, such as hydrogen pipelines and hydrogen production sites.

\subsection{Existing hydrogen production capacity}

Hydrogen is used as an industrial gas in many process industries throughout Europe. The total industrial hydrogen consumption in Europe is estimated to be about 61bn cubic metres (in 2003). The majority of this hydrogen was consumed by two industries: in oil refineries (ca. 50\%) and in the production of ammonia (ca. 32\%). 'The total production of hydrogen in the European Union amounts to $80 \mathrm{bn}^{3}$ (Steinberger-Wilckens, Trümper, 2007b) - which means that some overcapacity exists. 
The number of hydrogen production sites in each NUTS II region was counted. The ranking of the regions is based on the following score: 1 : one or two production sites, 2: three to five production sites, 3: six to eight production sites, 4: nine to fourteen production sites. It was not possible to look at the specific production processes of these facilities within the scope of this study.

The most important clusters of hydrogen production are in the Benelux-countries, the RhineMain area, the Midlands in the UK, southern France, and in northern Italy; but regions on the rim of the European Union such as Ireland, Finland Lithuania, North East Spain and Romania also produce hydrogen. Moreover, it is interesting to note that the new member states have many $\mathrm{H} 2$ production sites in total.

\subsection{Existing hydrogen pipeline infrastructure}

The Roads2Hycom project identified 15 large hydrogen pipeline networks in different parts of Europe, with a total length of nearly 1600 km (Perrin, Steinberger-Wilckens, Trümper, 2007). These pipeline networks are operated by firms such as Air Liquide, Linde Gas and Air Products. Pipelines are located in western Belgium, southern and western Netherlands, the German regions North-Rhein Westfalen, Sachsen and Sachsen-Anhalt and in the three regions of eastern France (incl. South-East France). The length of the pipelines is measured in km and mapped at NUTS II level. A ranking of the areas is based on the following score: 1: 2-25 km, 2: 26-61 km, 3: 62-163 km, and 4: 164-284 km. Figure 2 shows the geographical distribution of hydrogen production sites and hydrogen pipelines respectively.

\section{INSERT FIGURE 2 ABOUT HERE}

\subsection{Relationship between high-level H2FC regions and existing hydrogen infrastructure}

A total score for existing infrastructure and production capacity was calculated by summarising the score for production sites, and the length of $\mathrm{H} 2$ pipelines respectively. We then 
grouped the NUTS II regions based on their score on existing infrastructure into 3 groups: High score: 4-8 points, Medium score: 2-3 points and Low score: 1 point or less. The distribution of the 16 high activity H2FC regions between the three groups can be seen in Table 2 . Only 4 of the high activity H2FC regions score high on existing infrastructure and production capacity (Düsseldorf (DEA1) and Cologne (DEA2) in Nordrhein-Westphalia, Nord Pas-de-Calais (FR30) and Lombardy (ITC4) in Northern Italy). Half of the high activity regions score 2-3 points (Medium) on existing infrastructure, and four regions score 1 point or less (Low).

\section{INSERT TABLE 2 ABOUT HERE}

This means that we cannot conclude that existing $\mathrm{H} 2$ production capacity and $\mathrm{H} 2$ pipelines play a dominant role when regions decide to engage in H2FC activity. However, the analysis highlights four regions that have a high activity level and a high H2 capacity: Düsseldorf and Cologne in Nordrhein-Westphalia, Nord - Pas-de-Calais in France, and Lombardy in Northern Italy. Given that existing H2 infrastructure (production capacities and pipelines) is rewarding for H2FC development, these four regions seem to have comparative advantages for carrying out large-scale lighthouse projects.

\section{Correlation between regions' level of H2FC activities and their score in the EU's Regional Innovation Scoreboard}

The Regional Innovation Scoreboard 2006 was conducted by the Maastricht Economic and social Research and training centre on Innovation and Technology (MERIT). It measured seven innovation indicators: human resources in science and technology, participation in life-long learning, public and private R\&D, patent applications, and employment in mediumhigh and high-tech manufacturing. It indicates the general innovation climate, based on quantitative data in a region. The scores of the scoreboard data lie within an interval of 0 to 1, whereby the region with the highest ranking score has 0.90 (Stockholm, Sweden). 
For the purposes of this study, the Regional Innovation Score can be split into three categories; the bottom third, the middle third and the highest third. Of the 16 highest placed H2FC regions, 10 (or 62.5\%) are also among the top third most innovative regions. (See table 3).

\section{INSERT TABLE 3 ABOUT HERE}

This clearly indicates that H2FC activity takes place in regions that are generally innovative. This, in turn confirms the general thesis in cluster theory that greater spillover will occur where knowledge concentration is high beforehand (so-called endogenous growth theory). Given that these regions also perform better (which has not been analysed here), the results suggest that innovative regions have been faster in their attempts to promote H2FC activity. It also suggests that innovative regions find it easier to jump onto new technological paths, or are at least keener to take a chance on new and uncertain technology.

The high activity H2FC regions in the medium third are the Italian regions - Toscana, Piedmont and Lombardy, the UK-region Wales, and the German region Düsseldorf. The only high activity H2FC region in the bottom third is Nord - Pas-de-Calais, a major centre for heavy industry in the 19th century (coal mines and steel mills). After a heavy recession in the 1970s and 1980s the region today focuses on tourism. This result also raises the question of to what extent H2FC demonstration activities can be used in a political agenda for improving a region's innovative capabilities in general.

\section{Assessing the presence of clusters in H2FC-regions}

This section compares the presence of likely future H2FC-related industrial clusters in highactivity H2FC regions. The aim is to investigate whether certain existing clusters are represented more frequently in high-activity H2FC regions than in the rest of Europe. 
The analysis is based on the cluster mapping carried out by the European Cluster Observatory. The European Cluster Observatory has carried out cluster analyses in 32 countries, with NUTS II regions as the geographical unit. The analysis defines clusters in accordance with Michael Porter's analysis of employment distribution in North America (Porter, 2003). The American study analysed the geographical distribution of employment in various industries, and found different patterns depending on the type of industry. The industries were grouped into three categories, showing their various geographical profiles:

- Local industries are present in all regions, as they serve local markets. They are not exposed to direct competition across regions and are characterised by lower wages, productivity and rates of innovation. According to the European Cluster Observatory, local industries account for around 57\% of all employment in Europe.

- Traded cluster industries experience advantages in choosing their location, and serve markets across regions. They have a tendency to 'cluster together', and are characterised by above average wages, together with higher productivity and levels of innovation. The cluster sector accounts for about 37\% of European employment.

- Natural resource-based industries are located close to the deposits of the natural resources they exploit, and are therefore also geographically concentrated, but for other reasons. Around 5\% of the European workforce is employed in natural resource-based industries.

From the perspective of creating a hydrogen economy in all parts of society, all three industry groups will be affected. Local industries will be affected, either as users of new hydrogen products or as retailers. The natural resource-based industries will be affected, as hydrogen is not an energy source in itself, but needs to be produced using fossil energy sources, bio re- 
sources or similar. But, in the development phase of a new technological trajectory, the most important industrial actors should be found within the Traded Cluster Industries.

The European Cluster Observatory has divided the 'Traded cluster industries' into 38 cluster categories (see www.clusterobservatory.eu). They have categorised a cluster's strength in terms of size, specialisation and focus, so as to measure sufficient critical mass to develop the type of spillover and linkages that create positive economic effects. In the Cluster Observatory's evaluation, a cluster present in a given region receives between one and three stars, depending on the strength of the cluster. However, in our study we do not distinguish between the number of stars, but only focus on whether or not a cluster is present in the given region.

We have calculated a Cluster Quotient (CQ) for each of the 38 clusters. The CQ is a measure for collocation of H2FC activities and clusters. The CQ compares the proportion of clusters (in the same cluster category) located in the 16 high activity H2FC regions to the proportion of the total number of clusters (in the same cluster category) in all the 258 regions (see equation).

The Cluster Quotient is thus calculated as:

$\mathbf{C Q i}=(\mathbf{A i} / \mathbf{B}) /(\mathbf{C i} / \mathbf{D})$;

Where:

$\mathbf{i}$ is a cluster category according to the Cluster Observatory, e.g. Automotive

$\mathbf{A i}$ is the number for i clusters in all high activity H2FC regions

B is the number of all high activity H2FC regions (=16)

$\mathbf{C i}$ is the number of all i-type clusters (e.g. automotive) in all regions analysed by the Cluster Observatory

D is the number of all regions analysed by the Cluster Observatory (=258) 
A CQ $>2$ shows that the clusters are more frequently located in the high-level H2FC regions than in the rest of Europe. Table 4 shows the calculated CQ for the 38 clusters in Europe.

\section{INSERT TABLE 4 ABOUT HERE}

First and foremost, it is important to keep in mind that table 4 reveals a statistical measure for collocation of H2FC activities and clusters. The CQ does not measure whether or not there is a causal relationship between certain clusters and H2FC technology. Furthermore, clusters are analysed by studying the concentration of employment in industrial sectors. Employment with relevance for H2FC is most likely to be in companies’ R\&D departments, and comprises a relatively small part of the total workforce.. R\&D departments are often located where companies have their headquarters, or where there is a critical mass of skilled workers. Therefore, we assume that this collocation measure can provide us with some information about the clusters that play a role in H2FC development.

In general, table 4 reflects the result from the above analysis of the correlation between highly active H2FC regions and the regional innovation scoreboard. Clusters with a high CQ (>2) generally score higher in the indicators that make up the innovation scoreboard (human resources in science and technology, participation in life-long learning, public and private R\&D, patent applications, employment in medium-high and high-tech manufacturing) than clusters with a $\mathrm{CQ}<2$. Table 4 therefore confirms that an overall well-functioning innovation environment is important for regions' engagement in H2FC activity.

$\mathrm{H} 2 \mathrm{FC}$ technology is still at a stage where its relevance for many of the established clusters is limited. We have identified nine cluster categories that most likely play a role in the development and improvement of the technology. The nine clusters are highlighted in table 4 and presented in detail in Table 5, which shows the nine cluster categories, examples of industries and some examples of companies involved in H2FC development. 
Of the nine clusters with high relevance for H2FC technology, seven have a CQ higher than 2. Only transportation and heavy machinery have a CQ less than 2.

Transportation covers inventories and logistics, and distinguishes itself from the other clusters by being a service sector, providing actual transport and not the technology for transportation. The transportation sector will be among the large end-user groups of H2FC-based transportation technology. Heavy Machinery clusters are located in 4 out of the 16 H2FC clusters, so the results indicate, not surprisingly, that this cluster does not play a leading role in the regional $\mathrm{H} 2 \mathrm{FC}$ activities

TABLE 5 INSERTED ABOUT HERE

Chemicals (3.1), Power generation and transmission (3.1), and Oil and gas (2.4) are three clusters that are particularly relevant to the production and distribution of hydrogen. Automotive (2.4), communications equipment (2.9), aerospace (2.9), and production technology (2.9) are clusters with an interest in the various application options H2FC offers. The CQs show a high collocation between H2FC activities and these clusters.

This result can be explained by taking the market maturity of H2FC technologies into account. Firms interested in developing and demonstrating H2FC technologies in this early phase are seeking business opportunities to produce these technologies and provide the hydrogen, whereas firms that could potentially become end-users of such technologies (such as transportation) are likely to become involved at a later stage of the market development of these technologies.

Clusters most unlikely to support the development of $\mathrm{H} 2$ and fuel cell technologies such as Footwear, Furniture and Processed Food (beer, dairies, glass packages/wrapping) have a CQ 
$<1$. This also seems quite natural; firms in these sectors are only likely to become end-users of H2FC technologies when they are fully matured and competitive with other energy technologies.

In summary, a positive correlation has been found between the presence of clusters assessed to be H2FC-friendly and the high-activity H2FC regions. This indicates that specific clusters may play a role in driving the development of H2FC technology. However, the most important result of the study of Cluster Quotients seems to be a confirmation of the correlation between innovative regions (hosting innovative clusters) and H2FC technology development. An institutional set-up with favourable conditions for innovation is therefore seen as extremely important in promoting innovation activities in the field of H2FC.

This study of the role of regions in H2FC development has a preliminary character, and needs to be followed up by more in-depth studies. In particular, studies of the relationship between certain clusters and H2FC technology would be of interest. A study of the institutional set-up at the regional governance level and how to improve this through innovation policies would also be very interesting, and would be fruitful for the regional engagement in H2FC development in the future.

\section{Conclusions}

In the introduction to this article we raised a number of research questions. In the following section we will try to answer these questions and discuss their implications for energy and regional policy.

First of all, we can conclude that geography and cluster aspects seem to matter in establishing a European H2FC technology innovation system. It is clear that some regions are more active in the formative phase of H2FC innovation systems than others. 
Regions with the highest level of H2FC activities are found in various places in Europe, and, in many cases, the clustering of activities in neighbouring regions matches the location of partnerships or co-operative H2FC initiatives. In southern Scandinavia, the region matches the location of the ‘Scandinavian Hydrogen Highway Partnership’ (SHHP). The federal state North-Rhine-Westphalia in Western Germany might benefit from the activities carried out by the 'Fuel Cell and Hydrogen Network NRW'. In northeast Spain, there is the Aragon hydrogen initiative started by the Spanish Ministry of Industry in 2002. And in the case of northern Italy, there have been a number of projects carried out over the last decade - in Lombardy: the Zero Regio project in Mantova, the Bicocca Project in Milan, and the Arese project in Arese; and in Tuscany: the HBUS project in Florence and the Arezzo project. These geographical patterns of H2FC activities indicate that some European regions are building up critical-mass in the field of H2FC.

Secondly, the relationship between the early adoption of H2FC activity and existing hydrogen production capacities and pipeline infrastructure in regions is weak. Indeed, small projects can be carried out with on-site hydrogen production and do not require existing production or pipeline infrastructure. So the latter should not be seen as prerequisites for engagement with H2FC. However, the existence of production capacities and infrastructure is no doubt a positive factor for the implementation of large-scale projects and the development of H2FC clusters.

Thirdly, it can be concluded that regions which are very active in pursuing H2FC deployment are typically also generally innovative regions. This finding is consistent with endogenous growth theories and thus confirms the hypothesis that innovative regions can more easily engage with and advance in H2FC technology. Less innovative regions may, therefore, need specific support schemes to help them engage with H2FC. However, such support 
should be subject to the condition that the less innovative region in question disposes of some other success factors (e.g. hydrogen production infrastructure) which promise to make the investment a rewarding one. In any case, it is important to be aware of the extent of the hydrogen chain and that efforts are needed at all stages. It is as yet too early to tell where the breakthrough will occur that can make hydrogen competitive with incumbent technologies. Less innovative regions might be engaged in development paths which could lead to breakthroughs in niche markets that can improve the overall technology. It is therefore not recommendable to cut-off less innovative regions from funding sources.

Fourthly, the most active regions in the field of H2FC are characterised by the location of innovative clusters - a fact which confirms the importance of an overall well-functioning innovation system for the development of emerging technologies. Furthermore, some of the industrial clusters located in the highly active H2FC regions can be characterised as favourable for the development of H2FC. This relationship is particularly strong for clusters in chemical products, power generation, production technology, oil and gas, and automotive and aerospace technology - a fact which reflects the early stage of H2FC market development. In fact, investment in other H2FC applications depends on the advances in hydrogen generation and fuel cell technology. The relative importance of industries that provide enduse applications (such as transportation) is likely to increase at a later stage in the formation of the market for the technology. The decision of local and/or European-level authorities on whether to support a regional initiative should, therefore, take the specific regional industrial cluster structure and the general stage of market development into account.

This article has merely provided a preliminary insight into the economic geography of H2FC development. Additional studies of the character of regional innovation systems and how they can facilitate H2FC development through innovation and cluster policy are needed to pave the way for a hydrogen economy. Another interesting issue this article has revealed is 
that of the benefits and synergies the agglomeration of activities in neighbouring regions seems to have for H2FC development. This relationship also requires further study before qualified policy implications can be drawn.

\section{Acknowledgement}

This article is one of the results of the integrated project Roads2Hycom, supported by the European Commission's sixth framework programme. The project was conducted by a consortium of 29 partners from industry, research institutes and universities.

The authors would especially like to thank Raimund Bleischwitz and Nikolas Bader (College of Europe), Sören Christian Trümper (PLANET GbR), Susanne Shaw and Paola Mazzucchelli (JRC-IFE) for valuable contributions to and comments on this article.

\section{References}

Andersen, M. M.: Eco-Innovation Indicators. European Environment Agency, Copenhagen, February 2006.

Anderson, T,; S. S. Serger, J. Sörvik and E. W. Hansson, The Cluster Policies Whitebook, International Organisation for Knowledge Economy and Enterprise Development (IKED), 2004. http://www.iberpymeonline.org/Documentos/TheClusterPoliciesWhitebook.pdf (See also www.iked.org).

Asheim, B., and Gertler, M.S., (2004), The Geography of Innovation: Regional Innovation Systems, in Fagerberg, J., et al (2004), The Oxford Handbook of Innovation, Oxford University Press. 
Bergek, A.; Marko Hekkert and Staffan Jacobsson (2007), Functions in innovation systems: A framework for analysing energy system dynamics and identifying goals for systembuilding activities by entrepreneurs and policy makers. RIDE/IMIT Working Paper No. 84426-008, www.chalmers.se/tme/EN/centers/ride

Breschi, S., and Malerba, F., (1997), “Sectoral Innovation Systems: Technological Regimes, Schumpeterian Denamics, and Spatial Boundaries,” in Edquist, C., (ed.) (1997), Systems of Innovation: Technologies, Institutions and Organizations, London: Pinter.

Carlson, B., and Stankiewicz, R., (1991), “On the nature, functions and composition of technological systems,” in Journal of Evolutionary Economics, 1, pp. 93-118, Berlin: Springer.

Cooke, P., (2001), “Regional Innovation Systems, Clusters, and the Knowledge Economy,” in Industrial and Corporate Change, 10 (4), pp. 945-74.

Cooke, P. (2002) Knowledge Economies: Clusters, Learning and Cooperative Advantage, Routledge, London

Godoe, H. and S. Nygaard (2006), Systems failure, innovation policy and patents: Fuel cells and related hydrogen technology in Norway 1990-2002, Energy Policy 34 1697-1708

Hekkert, M.P., et al. (2006), “Functions of innovation systems: A new approach for analysing technological change,” in Technological Forecasting \& Social Change, Elsevier.

Jacobsson, S., and Bergek, A., et al. (2004), “Transforming the energy sector, the evolution of technological systems in renewable energy technology,” in Industrial and Corporate Change, vol. 13, no. 5, pp. 815-849 
Lee, S. K.; G. Mogi; J. W. Kim, 2008, The competitiveness of Korea as a developer of hydrogen energy technology: The AHP approach, Energy Policy, 36, 1284-1291.

Lundvall, B.A., eds. (1992) National Systems of Innovation: Towards a Theory of Innovation and Interactive Learning, Printer, London

Lundvall, B. A. and Borrás, (1999): The Globalising Learning Economy: Implications for Innovation Policy, Luxembourg: Office for Official Publications of the European Communities

Malerba, F., (2002), “Sectoral systems of Innovation and Production,” in Research Policy 31, pp.247-64

Midttun, A.; Anne-Louise Koefoed (2005), Green Innovation in Nordic Energy Industry: Systemic Contexts and Dynamic Trajectories. In Matthias Weber \& Jens Hemmelskamp, Towards Environmental Innovation Systems, Springer Verlag, 2005.

Perrin, J.; Robert Steinberger-Wilckens and Sören Christian Trümper (eds.), DELIVERABLE 2.1 AND 2.1a "European Hydrogen Infrastructure Atlas” and "Industrial Excess Hydrogen Analysis”. PART III: Industrial distribution infrastructure, PLANET GbR, Oldenburg, Germany, Document Number: R2H2007PU.1 3 July 2007. http://www.ricardo.com/roads2hycom/pub_download.asp?PageIndex=1

Pieter Mans, Floortje Alkemade, Tessa van der Valk, Marko P. Hekkert (2008), Is cluster policy useful for the energy sector? Assessing self-declared hydrogen clusters in the Netherlands, Energy Policy, Vol. 36, No 4, pp1375-1385 
Porter M. (2000): "Locations, clusters, and company strategy", in Clark, G., Feldman, M.,

Gertler, M. (Eds), The Oxford Handbook of Economic Geography, Oxford University Press, Oxford, pp.253-74.

Porter, M. (2003): The economic performance of regions, Regional Studies, pp. 549-478, vol. 37, 6\&7, 2003.

Seymour, E. H.; F. C. Borges , R. Fernandes, 2007, Indicators of European public research in hydrogen and fuel cells - An input-output analysis, Int. J. of Hydrogen Energy, 43, 32123222.

Shaw, S. and Paola Mazzucchelli (2007a), Results from call for community registration of interest: Mapping analysis of potential hydrogen communities in Europe, Joint Research Centre - Institute for Energy, Document Number: R2H3011PU.1, September 2007.

Shaw, S. and Paola Mazzucchelli (2007b), PROFILING OF HYDROGEN COMMUNITIES IN EUROPE: A FRAMEWORK FOR SELF-EVALUATION \& ADVICE ON SUCCESS FACTORS, Joint Research Centre - Institute for Energy, Document Number: R2H3010PU.2; December 2007

Steinberger-Wilckens, R.; Sören Christian Trümper (eds.) (2007a), Mapping of existing European Hydrogen Demonstration Sites, PLANET GbR, Oldenburg, Germany, Document Number: R2H2005PU.1, 19 April 2007 http://www.ricardo.com/roads2hycom/pub_download.asp?PageIndex=1

Steinberger-Wilckens, R.; Sören Christian Trümper (eds.) (2007b), DELIVERABLE 2.1 AND 2.1a "European Hydrogen Infrastructure Atlas" and "Industrial Excess Hydrogen 
Analysis” Executive Summary of Part I, II, III; PLANET GbR, Oldenburg, Germany; Document Number: R2H2004PU.1; 3 July 2007

http://www.ricardo.com/roads2hycom/pub_download.asp?PageIndex=1

Sölvell, Ö, Lindqvist, G., and Ketels, C. (2003): The Cluster Initiative Greenbook, 
Tables (including captions)

(Note! Figures uploaded separately, figure captions added on the last page of this document)

Table 1: Distribution of H2FC activities in the 16 most active regions in Europe in the field of H2FC. Listed according to NUTS II identification code.

\begin{tabular}{|c|c|c|c|c|c|c|c|c|}
\hline \multicolumn{2}{|c|}{ NUTS II region } & \multicolumn{2}{|c|}{$\begin{array}{c}\text { Demonstration } \\
\text { Sites } \\
\end{array}$} & \multicolumn{2}{|c|}{$\begin{array}{c}\text { Fuelling sta- } \\
\text { tions }\end{array}$} & \multicolumn{2}{|c|}{$\begin{array}{c}\text { Registration of } \\
\text { Interest }\end{array}$} & \multirow{2}{*}{$\begin{array}{l}\text { H2FC- } \\
\text { SCORE } \\
\text { Total points } \\
\end{array}$} \\
\hline Code & Name & count & point & count & point & count & point & \\
\hline DE11 & Stuttgart & 3 & 2 & 5 & 3 & 0 & 0 & 5 \\
\hline DE21 & Oberbayern & 1 & 1 & 5 & 3 & 1 & 1 & 5 \\
\hline DE30 & Berlin & 5 & 3 & 3 & 2 & 1 & 1 & 6 \\
\hline DE60 & Hamburg & 4 & 3 & 1 & 1 & 1 & 1 & 5 \\
\hline DEA1 & Düsseldorf & 3 & 2 & 1 & 1 & 2 & 2 & 5 \\
\hline DEA2 & Cologne & 3 & 2 & 1 & 1 & 1 & 1 & 4 \\
\hline DK00 & Denmark & 17 & 4 & 9 & 4 & 3 & 3 & 11 \\
\hline ES30 & Comunidad de Madrid & 4 & 3 & 1 & 1 & 0 & 0 & 4 \\
\hline FR30 & Nord - Pas-de-Calais & 4 & 3 & 1 & 1 & 1 & 1 & 5 \\
\hline IS & Iceland & 5 & 3 & 1 & 1 & 1 & 1 & 5 \\
\hline ITC1 & Piemont & 3 & 2 & 1 & 1 & 2 & 2 & 5 \\
\hline ITC4 & Lombardy & 2 & 2 & 3 & 2 & 1 & 1 & 5 \\
\hline ITE1 & Toscana & 1 & 1 & 4 & 3 & 2 & 2 & 6 \\
\hline $\mathrm{NO} 04$ & Agder and Rogaland & 2 & 2 & 3 & 2 & 1 & 1 & 5 \\
\hline SEOA & Western Sweden & 3 & 2 & 0 & 0 & 2 & 2 & 4 \\
\hline UKL & Wales & 4 & 4 & 0 & 0 & 1 & 1 & 5 \\
\hline
\end{tabular}


Table 2: Relationship between 16 high-activity H2FC regions and existing infrastructure

\begin{tabular}{|l|c|}
\hline $\begin{array}{l}\text { Total existing infrastructure and production capacity } \\
\text { score }\end{array}$ & $\begin{array}{l}\text { Count of high activity } \\
\text { H2FC regions }\end{array}$ \\
\hline High score on existing infrastructure (>3 points) & $4(25 \%)$ \\
\hline Medium score on existing infrastructure (2-3 points) & $8(50 \%)$ \\
\hline Low score on existing infrastructure (0-1 points) & $4(25 \%)$ \\
\hline
\end{tabular}


Table 3: Distribution of the 16 high activity H2FC regions over the 358 NUTS II regions' score in the European Regional Innovation Scoreboard

\begin{tabular}{|l|c|}
\hline $\begin{array}{l}\text { Score in the Regional } \\
\text { Innovation Scoreboard }\end{array}$ & $\begin{array}{l}\text { Number of high activity H2FC } \\
\text { regions (top 16 in Table 1) }\end{array}$ \\
\hline Highest third & 10 \\
\hline Medium third & 5 \\
\hline Bottom third & 1 \\
\hline
\end{tabular}


Table 4: Cluster Quotients

\begin{tabular}{|c|c|}
\hline Cluster Category & CQ \\
\hline Medical Devices & 4,7 \\
\hline Publishing & 4,4 \\
\hline Distribution service & 4,3 \\
\hline Analytical Instruments & 3,9 \\
\hline IT & 3,9 \\
\hline Biopharmaceuticals & 3,1 \\
\hline $\begin{array}{l}\text { Power generation and } \\
\text { transmission }\end{array}$ & 3,1 \\
\hline Chemicals & 3,1 \\
\hline Sporting & 2,9 \\
\hline Production Tech. & 2,9 \\
\hline Aerospace & 2,9 \\
\hline $\begin{array}{l}\text { Communications } \\
\text { equipment }\end{array}$ & 2,9 \\
\hline Forest products & 2,8 \\
\hline Lighting & 2,8 \\
\hline Plastics & 2,7 \\
\hline Entertainment & 2,4 \\
\hline Jewellery & 2,4 \\
\hline Oil and Gas & 2,4 \\
\hline Automotive & 2,4 \\
\hline Business Services & 2,1 \\
\hline Building Fixtures & 2,0 \\
\hline Constr. Materials & 2,0 \\
\hline Tobacco & 1,9 \\
\hline Education & 1,6 \\
\hline Leather & 1,5 \\
\hline Heavy Machinery & 1,4 \\
\hline Finance & 1,4 \\
\hline Agricultural & 1,4 \\
\hline Textiles & 1,3 \\
\hline Transportation & 1,3 \\
\hline Fishing & 1,3 \\
\hline Hospitality & 1,2 \\
\hline Metal manufacturing. & 1,1 \\
\hline Footwear & 0,9 \\
\hline Apparel & 0,8 \\
\hline Furniture & 0,7 \\
\hline Food & 0,7 \\
\hline Construction & 0,7 \\
\hline
\end{tabular}


Table 5: Cluster categories with interest to H2FC development

\begin{tabular}{|c|c|c|}
\hline Cluster categories & Industry examples & $\begin{array}{l}\text { Examples from European } \mathrm{H} 2 \\
\text { and Fuel Cell Technology Plat- } \\
\text { form's NEW-IG members }\end{array}$ \\
\hline $\begin{array}{l}\text { Oil \& Gas Products and Ser- } \\
\text { vices }\end{array}$ & refineries & $\begin{array}{l}\text { Statoil Hydro ASA, Gaz de } \\
\text { France, Shell Hydrogen BV, } \\
\text { Total France, Intelligent Energy, } \\
\text { ILT Technology }\end{array}$ \\
\hline Automotive & $\begin{array}{l}\text { motor vehicles and } \\
\text { components }\end{array}$ & $\begin{array}{l}\text { Daimler, Adam Opel GmbH, } \\
\text { Volkswagen, Cento Ricerche } \\
\text { Fiat, AVL List GmbH, Volvo, } \\
\text { Rolls Royce Fuel cell system, } \\
\text { RiverSimple LLP, Intelligent En- } \\
\text { ergy, }\end{array}$ \\
\hline $\begin{array}{l}\text { Power Generation and } \\
\text { Transmission }\end{array}$ & generators & $\begin{array}{l}\text { Siemens, E.ON Sweden AB, } \\
\text { EWE AG, GAMESA Corpo- } \\
\text { racion Tecnologica, Intelligent } \\
\text { Energy, Ceres Power Ltd. }\end{array}$ \\
\hline Heavy Machinery & tractors, locomotives & $\begin{array}{l}\text { Wärtsilä Finland, Gruppo Sapio, } \\
\text { Ansaldo Fuel Cells, Nucellsys }\end{array}$ \\
\hline Chemical Products & $\begin{array}{l}\text { chemicals, industrial } \\
\text { gases }\end{array}$ & $\begin{array}{l}\text { Linde Gas, BASF Fuel Cells } \\
\text { GmbH, ILT Technology, BP In- } \\
\text { ternational }\end{array}$ \\
\hline Production Technology & tanks & Topsoe Fuel Cells, Nucellsys, \\
\hline Transportation and Logistics & freight, air transport & $\begin{array}{l}\text { Rail Safety and Standard } \\
\text { Boards }\end{array}$ \\
\hline Aerospace & APU on aircraft & $\begin{array}{l}\text { Intelligent Energy, EADS } \\
\text { Deutschland }\end{array}$ \\
\hline Communications Equipment & $\begin{array}{l}\text { portable applications, } \\
\text { mobile, computers }\end{array}$ & \\
\hline
\end{tabular}


FIGURE captions:

Figure 1: Map showing combined H2FC activity level at NUTS II level.

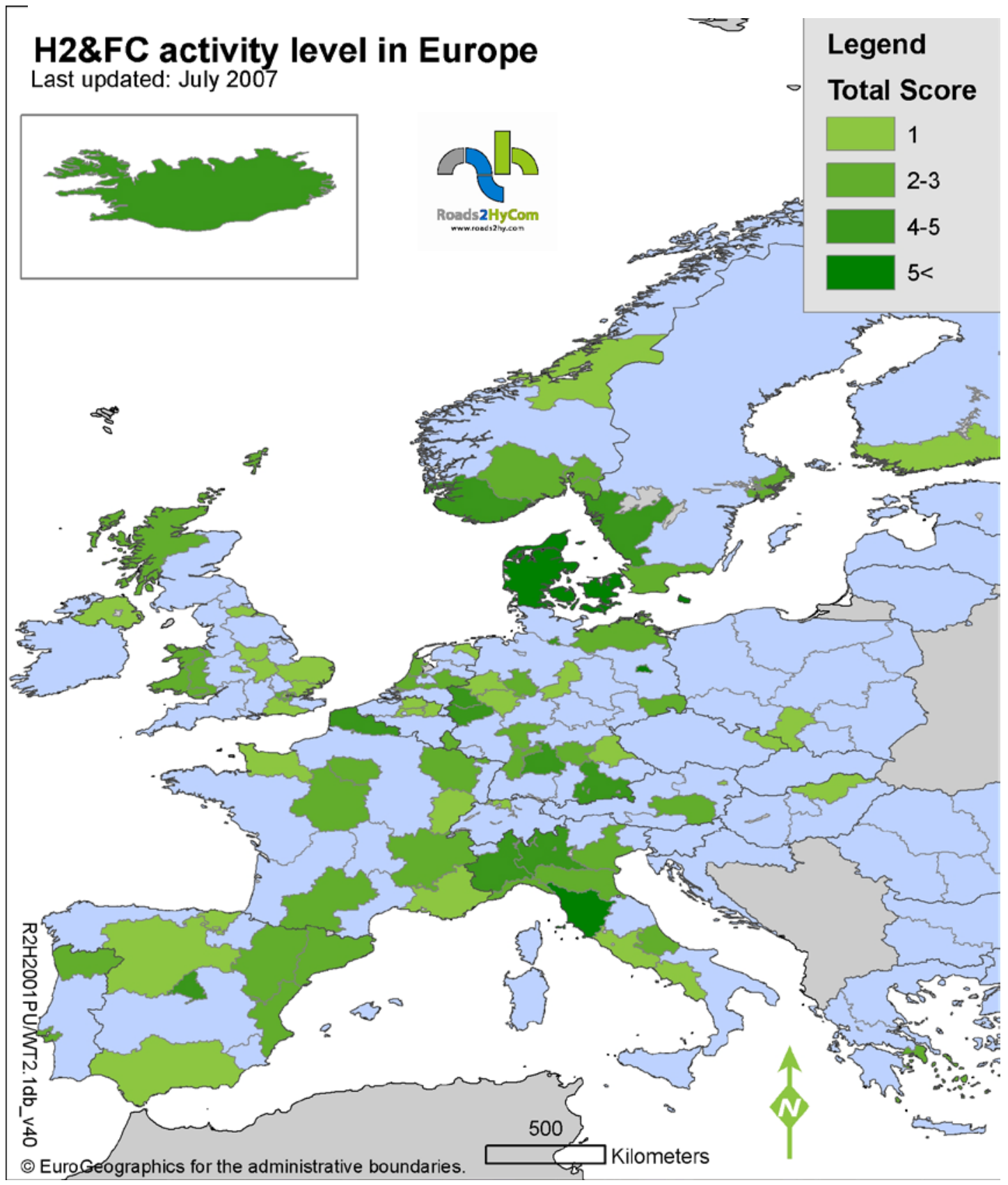


Figure 2: Left: Total H2 Production Sites in Europe, Right: H2 Pipelines in Europe
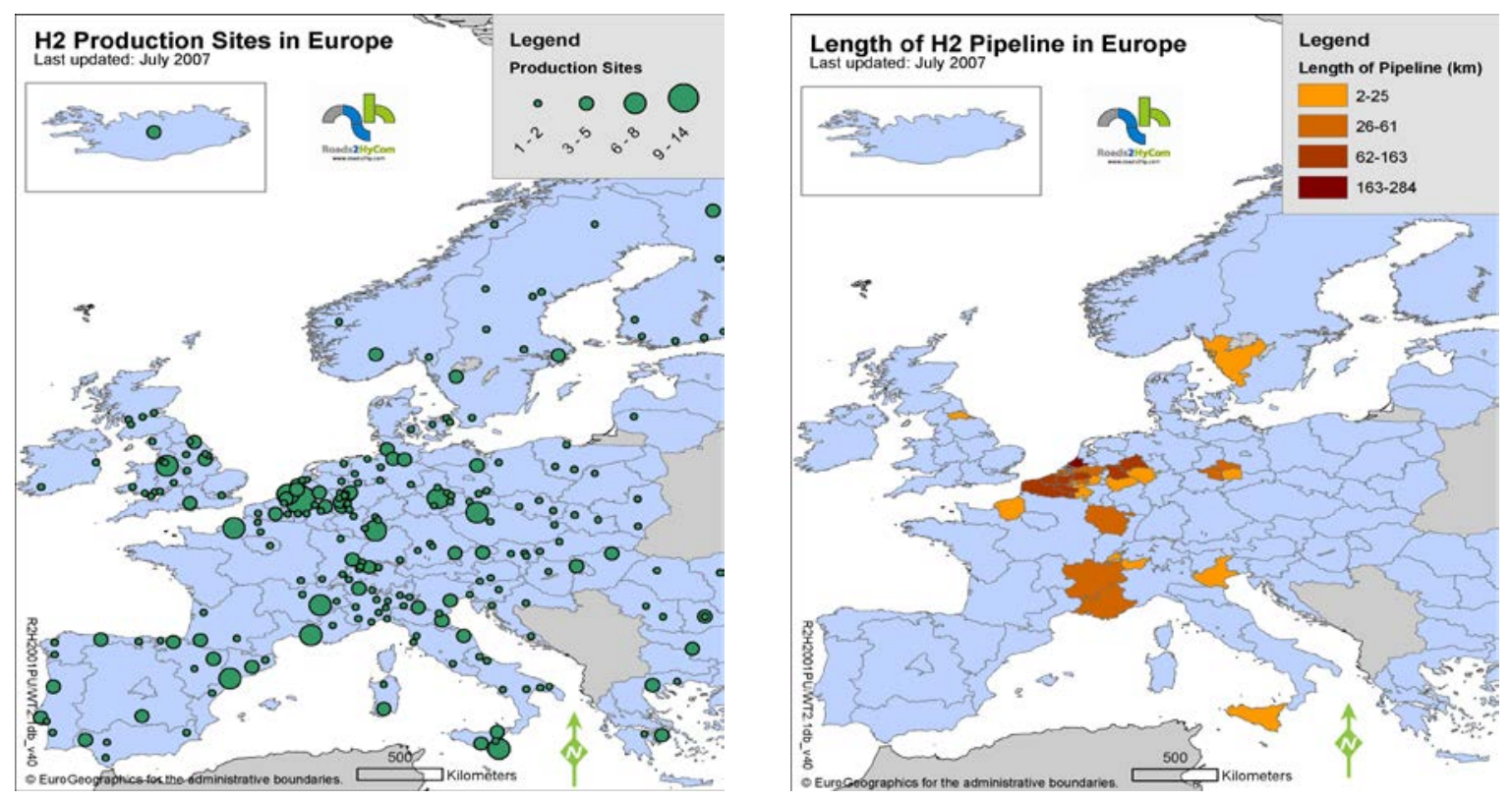